\title{
Ssciendo
}

DOI 10.2478/afepuc-2020-0009

(C) Acta Facultatis Educationis Physicae Universitatis Comenianae 2020, 60(1): 105-116

\section{GENDER DIFFERENCES IN SUBJECTIVE QUALITY OF LIFE OF ELITE AND COMPETITIVE SPORTS GAMES PLAYERS \\ Juraj Nemček}

Comenius University in Bratislava, Faculty of Physical Education and Sports, Department of Sports Games, Slovakia

\begin{abstract}
Summary: The objective of the present study was to analyse subjective quality of life (S-QOL) throughout the quality of life indicators' (QOLIs) and quality of life domains' (QOLDs) satisfaction, and overall S-QOL among elite and competitive sports games players (i.e. players) and compare the SQOL between the male and female. The research sample comprised of 106 male players (mean age 27.2 \pm 1.96 years) and 28 female players (mean age $24.9 \pm 1.45$ years). A standardized Subjective Quality of Life Analyses (S.QUA.L.A.) was used as a primary research method. No significant differences were found in overall S-QOL neither in QOLDs' satisfaction between male and female players. Male players present significantly higher satisfaction with leisure activities, sport and work than females. Both genders equally declared the highest S-QOL by social relation and physical health/level of independence and the lowest level of S-QOL by psychological health/spirituality.
\end{abstract}

Keywords: elite and competitive athletes, sports games players, male and female players, indicators, domains

\section{Introduction}

Elite athletes' lifestyles are subordinated to sport, which becomes a way of their life (Stambulova 1994) and significantly affect their quality of life (QOL) from different perspectives. High-performance sport (elite and competitive), because it is highly organized, physically and mentally challenging, including its environment, may not lead to the improvement of a quality of life improvement and may even seriously undermine it (Simon \& Docherty 2014; Ruiz et al. 2004). The World Health Organization (WHO) defines Quality of Life (QOL) as an Individual's own subjective perception of their position in life in relation to their particular goals, expectations, standards and concerns. It is a broad-ranging subjective 
quality of life (S-QOL) concept affected in a complex way by the person's satisfaction with physical health, psychological state, level of independence, social relationships, and their relationship to salient features in their environment" (WHOQOL Group 1995). High-level competitive athletes (elite and competitive) participate in sport under conditions that present considerable physical and psychosocial stressors (Lundqvist 2011). Elite and competitive athletes, sports game players (i.e. players) are not an exception, must continually strive for a success in a highly competitive and stressful environment; thus, high-level competitive sport can have either a detrimental or beneficial influence on the S-QOL and health of athletes (Bartholomew et al. 2011). Training and exercise are crucial components of elite and competitive athletes' daily lives (Durand-Bush \& Salmela 2002) and are often mentioned as reasons for their S-QOL (Loland 1999). Most elite and competitive athletes report high SQOL (Stephan \& Bilard 2003) because of the euphoric effect of exercise (McAllister et al. 2001) and the intensity emerging from the lifestyle in high level sport (Gearing 1999; Mikulič et al. 2015).

The objective of the present study was to analyse subjective quality of life throughout (1) QOL indicators' (QOLIs) satisfaction, (2) QOL domains' (QOLDs) satisfaction and (3) overall S-QOL among elite and competitive sports games players and compare the S-QOL between male and female players.

\section{Methods}

\section{Participants and data collection}

The research sample comprised of 134 elite and competitive sports games players (ECSGPs; i.e. players) categorized by gender: (1) male players $(\mathrm{n}=106$; mean age $27.2 \pm$ 1.96 years) and $(2)$ female players $(n=28$; mean age $24.9 \pm 1.45$ years $) .40 .7 \%$ were football and indoor football players, $16.4 \%$ ice hockey and floorball players, $15.7 \%$ tennis, table tennis and badminton players, $10.4 \%$ volleyball players, $12.0 \%$ basketball and $8.2 \%$ handball players. Participants were contacted through representatives of national sport organisations/associations around Slovakia. Some questionnaires were sent electronically by representatives of the organisations and some were passed out at the different meetings organised by national organisations. All data were collected for 2019 year's period and participants agreed to participate in the study and gave their written informed consent. The Ethics Committee of the Faculty of Physical Education and Sports, Comenius University in Bratislava (ref. no. 10/2019) had approved this research. 


\section{The Subjective Quality of Life Analysis (S.QUA.L.A)}

\section{The World Health Organisation Quality Of Life (WHOQOL)}

A standardized The Subjective Quality of Life Analysis (S.QUA.L.A) was used as a primary research method. S.QUA.L.A. is a multidimensional instrument. This multidimensional self-assessment method was created by Mathieu Zannotti in 1992 (Zannotti \& Pringuey 1992). This scale includes 23 indicators of life (QOLIs). It covers traditional areas (food, family relation etc.) and more abstract aspects of life (politic, justice, freedom, truth, beauty and art, love). We used second part of S.QUA.L.A. where for each QOLI, participants were asked to evaluate their degree of satisfaction using the 5-point rating scale. Score 1 (high satisfaction) meant the highest satisfaction and in the same time the highest level and score 5 (total disappointment) expressed the absolute insignificance of the particular indicator in life. The lower mean point score meant higher satisfaction with particular QOLI. For this study we modified the S.QUA.L.A. questionnaire by including one more indicator No. 16 "sport". We unified all 24 S.QUA.L.A. QOLIs into five quality of life domains (QOLDs) following WHOQOL (WHO User Manual 1998): (1) Physical Health and the Level of Independence; (2) Psychological Health and Spirituality; (3) Social Relationships; (4) Environment. Overall S-QOL was calculated by summarizing scores of all 24 QOLIs. In this study a Slovak version of the S.QUA.L.A. was used (Nemček et al. 2011).

\section{Data analyses}

The program IBM SPSS Statistics version 23.0 was used for data processing. The data were described using absolute and relative frequencies, including the mean $(\overline{\mathrm{x}})$ and standard deviation $( \pm \mathrm{SD})$. The Kolmogorov-Smirnov test was used to evaluate data normality and non-parametric Mann Whitney $U$-test was used to assess differences between two independent groups of male and female players. The rate of dependence (effect size) between the two samples of features was conveyed by means of the coefficient $r$ ( $r>0.90$ - very large effect size, $\mathrm{r}=0.70-0.90$ - large effect size, $\mathrm{r}=0.50-0.70$ - medium effect size, $\mathrm{r}=0.30$ 0.50 - small effect size, $r<0.29$ - very small effect size) proposed by Pett (1997). Wilcoxon Signed Ranks Test was used to determined differences between QOLDs (two related samples). The rate of effect size between the two related samples (QOLDs) was conveyed by means of the coefficient $d(\mathrm{~d}>1.30$ very large effect size, $\mathrm{d}=0.50-0.80$ large effect size, $\mathrm{d}$ $=0.20-0.50$ medium effect size, $\mathrm{d}<0.20-$ small effect size) proposed by Cohen (1988). The significance level was set at $\alpha \leq 0.05\left(^{*}\right)$ and $\alpha \leq 0.01(* *)$. In the current study, only one measurement has been made and two main groups of ECSGPs formed the study. 


\section{Results}

Table 1

S-QOL differences between male and female players (S.QUA.L.A.)

\begin{tabular}{|l|c|c|c|c|}
\hline \multirow{2}{*}{ QOLIs/Overall S-QOL } & \multicolumn{2}{|c|}{$\begin{array}{c}\text { Male players } \\
(\mathrm{n}=106)\end{array}$} & $\begin{array}{c}\text { Female players } \\
(\mathrm{n}=28)\end{array}$ & $\boldsymbol{U}$ \\
\cline { 2 - 3 } & \multicolumn{2}{|c|}{$\overline{\mathbf{x}} / \pm \mathbf{S D}$ (mean point score) } & & \\
\hline General health & $1.934 \pm 0.820$ & $2.250 \pm 0.887$ & 1184 & 0.080 \\
\hline Physical wellbeing & $1.915 \pm 0.782$ & $1.929 \pm 0.900$ & 1463 & 0.901 \\
\hline Psychological wellbeing & $2.057 \pm 0.728$ & $2.214 \pm 0.686$ & 1301 & 0.257 \\
\hline Home environment & $1.848 \pm 0.731$ & $1.964 \pm 0.838$ & 1379 & 0.578 \\
\hline Sleep & $2.000 \pm 0.781$ & $2.036 \pm 0.744$ & 1419 & 0.699 \\
\hline Family relations & $1.783 \pm 0.828$ & $1.893 \pm 0.916$ & 1397 & 0.605 \\
\hline Relations with others & $1.934 \pm 0.666$ & $2.000 \pm 0.608$ & 1412 & 0.641 \\
\hline Children & $2.100 \pm 0.775$ & $1.923 \pm 0.760$ & 347 & 0.492 \\
\hline Self-care & $2.009 \pm 0.710$ & $1.857 \pm 0.651$ & 1299 & 0.253 \\
\hline Love & $2.000 \pm 1.028$ & $2.107 \pm 1.499$ & 1403 & 0.693 \\
\hline Sexual life & $2.114 \pm 1.031$ & $2.346 \pm 1.231$ & 1240 & 0.450 \\
\hline Political situation & $3.505 \pm 0.959$ & $3.750 \pm 0.967$ & 1234 & 0.215 \\
\hline Religion/Spirituality & $2.657 \pm 1.073$ & $2.571 \pm 1.069$ & 1362 & 0.529 \\
\hline Rest in leisure & $2.217 \pm 0.840$ & $2.286 \pm 0.937$ & 1436 & 0.770 \\
\hline Leisure activities & $1.755 \pm 0.645$ & $2.071 \pm 0.663$ & $\mathbf{1 1 1 4} *$ & $\mathbf{0 . 0 2 0}$ \\
\hline Sport & $1.642 \pm 0.746$ & $2.036 \pm 0.744$ & $\mathbf{1 0 3 7 * *}$ & $\mathbf{0 . 0 0 7}$ \\
\hline Safety & $2.124 \pm 0.717$ & $2.036 \pm 0.793$ & 1363 & 0.515 \\
\hline Work & $2.123 \pm 0.859$ & $2.857 \pm 0.932$ & $\mathbf{8 3 8 * *}$ & $\mathbf{0 . 0 0 0}$ \\
\hline Justice & $3.010 \pm 1.014$ & $2.964 \pm 0.793$ & 1465 & 0.976 \\
\hline Freedom & $2.295 \pm 0.940$ & $2.074 \pm 0.917$ & 1239 & 0.270 \\
\hline Beauty and art & $2.472 \pm 0.707$ & $2.357 \pm 0.911$ & 1355 & 0.441 \\
\hline Truth & $2.604 \pm 0.953$ & $2.643 \pm 0.678$ & 1360 & 0.463 \\
\hline Finances & $2.664 \pm 0.888$ & $2.741 \pm 1.059$ & 1394 & 0.952 \\
\hline Food & $1.906 \pm 0.684$ & $1.786 \pm 0.568$ & 1368 & 0.468 \\
\hline Overall S-QOL & $\mathbf{2 . 1 9 6 \pm \mathbf { 0 . 4 0 6 }}$ & $\mathbf{2 . 2 8 9} \pm \mathbf{0 . 4 5 8}$ & $\mathbf{1 3 4 4}$ & $\mathbf{0 . 4 4 3}$ \\
\hline
\end{tabular}

Note. $U=$ Mann-Whitney U-test statistics; $p=$ statistical significance ( $p$-values $* \leq .05, * * \leq 01)$.

Mean point scores analyses of QOLIs'satisfaction in the group of male players showed the highest satisfaction with sport $(1.642 \pm 0.746$ points), leisure activities $(1.755 \pm 0.645$ points), family relations $(1.783 \pm 0.828$ points $)$, home environment (1.848 \pm 0.731 points $)$, food (1.906 \pm 0.684 points), physical wellbeing (1.915 \pm 0.782 points), social relations (1.934 \pm 0.666 points), altogether with the general health (1.934 \pm 0.820 points $)$. The mean scores of mentioned QOLIs didn't exceed 2.0 points of satisfaction rate (Table 1). The group of female 
players declared the highest satisfaction in their life with food $(1.786 \pm 0.568$ points $)$, selfcare $(1.857 \pm 0.651$ points $)$, family relations $(1.893 \pm 0.916$ points $)$, children $(1.923 \pm 0.760$ points), physical wellbeing $(1.929 \pm 0.900$ points $)$ and home environment $(1.964 \pm 0.838$ points) - QOLIs that did not exceed 2.0 points of the mean scores. On the other side, both groups of male and female players are the most dissatisfied in their life with the current political situation (males, $3.505 \pm 0.959$ points; females, $3.750 \pm 0.967$ points).

S-QOL evaluated by QOLIs' satisfaction according to participants' gender revealed significant differences only in three from twenty-four items (Table 1). Concretely, male players presented significantly higher satisfaction in their life with leisure activities $(\mathrm{U}=$ 1114, $\mathrm{p}=0.020, \mathrm{r}=0.235)$, sport $(\mathrm{U}=1037, \mathrm{p}=0.007, \mathrm{r}=0.256)$ and work $(\mathrm{U}=838, \mathrm{p}=$ $0.000, r=0.379$ ) compare female players. By mean point scores evaluation we found that male players were more satisfied in their life with $66.7 \%$ of QOLIs by lower mean point scores achievement compare female players. Summarising all twenty-four QOLIs we found out no significant differences in overall S-QOL between male and female players (Table 1).

Table 2

S-QOL differences between male and female players (WHOQOL)

\begin{tabular}{|l|c|c|c|c|}
\hline QOLDs & $\begin{array}{c}\text { Male players } \\
(\mathrm{n}=106)\end{array}$ & $\begin{array}{c}\text { Female players } \\
(\mathrm{n}=28)\end{array}$ & $\boldsymbol{U}$ \\
\cline { 2 - 5 } & \multicolumn{2}{|c|}{$\begin{array}{c}\overline{\mathbf{x}} / \pm \text { SD } \\
\text { (mean point score })\end{array}$} & \\
\hline $\begin{array}{l}\text { Physical health and level of } \\
\text { independence }\end{array}$ & $2.028 \pm 0.467$ & $2.125 \pm 0.441$ & 1328 & 0.388 \\
\hline $\begin{array}{l}\text { Psychological health and } \\
\text { Spirituality }\end{array}$ & $2.463 \pm 0.550$ & $2.476 \pm 0.577$ & 1446 & 0.834 \\
\hline Social relations & $1.986 \pm 0.572$ & $2.066 \pm 0.657$ & 1382 & 0.574 \\
\hline Environment & $2.254 \pm 0.456$ & $2.380 \pm 0.584$ & 1344 & 0.441 \\
\hline
\end{tabular}

Note. $U=$ Mann-Whitney $U$-test statistics; $p=$ statistical significance ( $p$-values $* \leq .05, * * \leq 01)$.

Table 3

Differences between QOLDs in male players

\begin{tabular}{|l|c|c|c|c|}
\hline QOLDs & $\begin{array}{c}\text { Physical health } \\
\text { and level of } \\
\text { independence }\end{array}$ & $\begin{array}{c}\text { Psychological health } \\
\text { and Spirituality }\end{array}$ & $\begin{array}{c}\text { Social } \\
\text { relations }\end{array}$ & Environment \\
\hline Physical health and & & $\mathbf{6 . 7 7 2}^{* *}$ & 1.143 & $\mathbf{5 . 5 1 5}^{* *}$ \\
level of independence & 1 & $\mathbf{0 . 0 0 0}$ & 0.253 & $\mathbf{0 . 0 0 0}$ \\
\hline Psychological health & & 1 & $\mathbf{7 . 0 3 6}^{* *}$ & $\mathbf{4 . 8 5 7}^{* *}$ \\
and Spirituality & & & $\mathbf{0 . 0 0 0}$ & $\mathbf{0 . 0 0 0}$ \\
\hline Social relations & & & 1 & $\mathbf{4 . 9 3 3 ^ { * * }}$ \\
& & & $\mathbf{0 . 0 0 0}$ \\
\hline
\end{tabular}




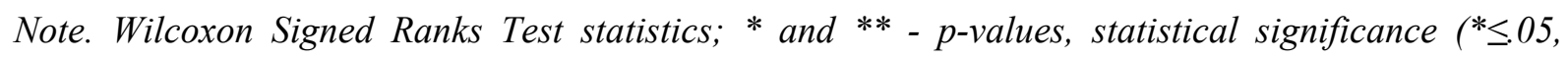
$* * \leq 01$ ).

Mean point scores analyses of QOLDs'satisfaction in the group of male players show the highest satisfaction with social relations (1.986 \pm 0.572 points $)$ and physical health and level of independence $(2.028 \pm 0.467$ points $)$ and the lowest satisfaction with psychological health and spirituality $(2.463 \pm 0.550$ points $)$. The group of female players displayed the same results than male players as they showed the highest satisfaction in their life also with social relations $(2.066 \pm 0.657$ points $)$ and physical health and level of independence $(2.125 \pm 0.441$ points) and the lowest satisfaction with psychological health and spirituality $(2.476 \pm 0.577$ points) (Table 2). No significant differences were found between two first QOLDs (social relations and physical health/level of independent) in both evaluated groups of male and female players, that indicates equally the highest satisfaction with social relations as well as with physical health/level of independence in S-QOL of male and female players (Table 3, 4). Significantly lowest S-QOL in male as well as female players were displayed by psychological health and spirituality domain (Table 3,4). In the group of male players significantly the highest dissatisfaction with psychological health a spirituality was declared in comparison with all QOLDs satisfaction as follows: social relations $(Z=7.036, p=0.000$, $\mathrm{d}=0.850)$, physical health/level of independence $(\mathrm{Z}=6.772, \mathrm{p}=0.000, \mathrm{~d}=0.852)$ and environment $(Z=4.857, p=0.000, d=0.413$ ) (Table 3$)$. In the group of female players significantly the highest dissatisfaction with psychological health a spirituality was revealed in comparison with two QOLDs satisfaction as follows: social relations $(Z=3.656, p=0.000$, $\mathrm{d}=0.663)$ and physical health/level of independence $(\mathrm{Z}=2.955, \mathrm{p}=0.003, \mathrm{~d}=0.683)$ (Table 4).

S-QOL assessed by QOLDs' satisfaction according to participants' gender revealed no significant differences in either QOLD (Table 2).

\section{Table 4}

Differences between QOLDs in female players

\begin{tabular}{|l|c|c|c|c|}
\hline QOLDs & $\begin{array}{c}\text { Physical health } \\
\text { and level of } \\
\text { independence }\end{array}$ & $\begin{array}{c}\text { Psychological health } \\
\text { and Spirituality }\end{array}$ & $\begin{array}{c}\text { Social } \\
\text { relations }\end{array}$ & Environment \\
\hline Physical health and & 1 & $\mathbf{2 . 9 5 5 * *}$ & 0.815 & $\mathbf{2 . 4 8 4 * *}$ \\
level of & $\mathbf{0 . 0 0 3}$ & 0.415 & $\mathbf{0 . 0 1 3}$ \\
independence & & 1 & $\mathbf{3 . 6 5 6}^{* *}$ & 0.718 \\
\hline Psychological & & & \\
\hline
\end{tabular}




\begin{tabular}{|l|l|l|c|c|}
\hline $\begin{array}{l}\text { health and } \\
\text { Spirituality }\end{array}$ & & $\mathbf{0 . 0 0 0}$ & 0.473 \\
\hline Social relations & & & 1 & $\mathbf{2 . 6 6 5}$ \\
& & & & $\mathbf{0 . 0 0 8}$ \\
\hline
\end{tabular}

Note. Wilcoxon Signed Ranks Test statistics; ${ }^{*}$ and ${ }^{* *}-p$-values, statistical significance $\left(^{*} \leq .05\right.$, $* * \leq 01)$.

Summarising observed data of the present study we can confirm no differences in satisfaction with QOLDs neither in overall S-QOL between male and female players. Male players show significantly higher satisfaction in their life with leisure activities, sport and work than female players. In $87.5 \%$ QOLIs'satisfaction were not revealed significant differences between male and female players. The highest S-QOL assessed by QOLDs' satisfaction was declared by social relations and physical health/level of independence in male as well as female ECSGPs and the lowest by psychological health/spirituality.

\section{Discussion}

The Slovak population $(\mathrm{n}=1107)$ assessing their S-QOL more positively (Nemček, 2016a). The Slovak population is the most satisfied in their life with QOLIs social relations, family relations, food and home environment. Negative S-QOL of the Slovak population pointing to political situation and justice (Nemček 2016a) The objective of the present study was to analyse S-QOL throughout (1) QOLIs' satisfaction, (2) QOLDs' satisfaction and (3) overall S-QOL among elite and competitive sports games players and compare the S-QOL between evaluated groups of players according to their gender. The results of the present study revealed the highest satisfaction with sport, leisure activities and family relations - as QOLIs in the group of male players and the highest satisfaction with food, self-care and family relations in the group of female players. Many studies were published investigating gender differences in S-QOL (Ladecká, Nemček \& Harčaríková 2019; Joanović et al. 2019; Nemček, Kurková \& Wittmannová 2019) and some researchers investigated S-QOL among males and females according to sport participation (Nemček 2016b; Nemček 2017; Pačesová, Šmela \& Kraček 2019). In the study of Tanabe at al. (2010) female athletes presented significantly lower health related quality of life scores on the happiness subscale and psychological well-being than male athletes. Comparing the results of the current study, male players achieved significantly higher satisfaction only with $12.5 \%$ QOLIs concretely sport, leisure activities and work than female players. But on the other side, no significant differences were found in QOLDs' satisfaction between male and female players. Elite athletes, in general without gender differentiation, report high life satisfaction during their 
career because of the living, loving relationship they develop with their sport (Werthner \& Orlick 1986). In the study of Correia et al. (2017) elite volleyball players $(n=32)$ declared significantly higher level of physical, psychological and social QOLDs comparing normative data - regular citizens. In the study of Nemček, Kraček \& Peráčková (2017) was found the highest S-QOL in the group of elite and competitive athletes comparing recreational athletes and inactive individuals, but not significant differences in S-QOL were found between elite/competitive athletes and recreational athletes.

The present study further revealed the highest S-QOL by the highest satisfaction with social relations and physical health domains declared by both genders of players. Following the results of Correia et al. (2017), the highest satisfaction with social relations can be explained by the fact that the athletes are inserted in a team ideal, where bonds of friendship are created due to the daily coexistence (Smith 2003), and focused on a common ideal: the success of the team. The scientific literature shows that competence in the areas of physical activity can often lead to social competence or social acceptance (Weiss \& Duncan 1992; Nemček 2014; Labudová, Nemček \& Bardiovský 2014; Eime et al. 2010). High satisfaction with physical health can be explained by the fact, that the players practice daily physical exercise, monitored by coaches and physical trainers, have qualified medical and psychological assistance in their respective teams and have balanced diets (Correia et al. 2017). These results reinforce the close association between sport and health, due to the role attributed to sport practice in the configuration of healthy lifestyles (Omorou 2013).

The results of the present study confirmed the lowest level of psychological health/spirituality in both genders of elite and competitive sports games players. These results can be caused by the findings of Rice et al. (2016) who suggested that elite athletes experience a broadly comparable risk of high-prevalence mental disorders (i.e. anxiety, depression) relative to the general population. Evidence regarding other mental health domains (i.e. eating disorders, substance use, stress and coping) is less consistent (Rice et al. 2016). Concretely, Australian elite athletes in the study of Gulliver et al. (2015) displayed depression (27.2\%), eating disorder (22.8\%), general psychological distress (16.5\%), social anxiety $(14.7 \%)$, generalised anxiety disorder $(7.1 \%)$, and panic disorder $(4.5 \%)$ as the reasons of very low psychological health domain in S-QOL of elite and competitive athletes.

\section{Conclusion}


Observed data of the present study reported no significant differences in overall SQOL as well as in QOLDs' satisfaction between male and female elite and competitive sports games players. In S-QOL male players present significantly higher satisfaction with leisure activities, sport and work than female players. Both genders equally showed significantly the highest S-QOL in social relation and physical health/level of independence and significantly the lowest level of S-QOL in psychological health/spirituality.

\section{Acknowledgement}

This scientific research was supported by the grant project of the Ministry of Education, Science, Research and Sport of the Slovak Republic VEGA No. 1/0409/19, "Sport as a tool of influencing the cognitive-evaluative component of the subjective well-being of people with health impairments".

\section{References}

1. BARTHOLOMEW, K.J., N. NTOUMANIS, R.M. RYAN \& C. THOGERSENNTOUMANI, 2011. Psychological need thwarting in the sport context: Assessing the darker side of athletic experience. In: Journal of Sport and Exercise Psychology. 33(1), pp. 75-102.

2. COHEN, J., 1988. Statistical Power Analysis for the Behavioural Sciences (2nd ed.). Hillsdale, NJ: Lawrence Erlbaum Associates Publishers.

3. CORREIA, R.F., A.N. RIBEIRO, J.F. BARBIERI, D. BRASIL, L. MOTTA, L.A.A. CASTANO \& M.G.C. SALVE, 2017. Quality of Life Levels in Brazilian Elite Female College Volleyball Players. In: International Journal of Sports Science. 7(1), pp. 6-9.

4. DURAND-BUSH, N. \& J.H. SALMELA, 2002. The development and maintenance of expert athletic performance: Perceptions of world and Olympic champions. In: Journal of Applied Sport Psychology. 14(3), pp. 154-171.

5. EIME, R.M., J.T. HARVEY, W.J. BROWN \& W.R. PAYNE, 2010. Does sports club participation contribute to health-related quality of life? In: Medicine and Science in Sports Exercise. 42(5), pp. 1022-1028.

6. GEARING, B., 1999. Narratives of identity among former professional footballers in the United Kingdom. In: Journal of Aging Studies. 13(1), pp. 43-58.

7. GUlliver, A., K.M. GRIFFITHS, A. MACKINNON, P.J. BATTERHAM \& R. STANIMIROVIC, 2015. The mental health of Australian elite athletes. In: Journal of Science and Medicine in Sports. 18(3), pp. 255-261.

8. JOANOVIĆ, E., H. KISVETROVÁ, D. NEMČEK, P. KURKOVÁ, B. ŠVEJDÍKOVÁ, J. 
ZAPLETALOVÁ \& Y. YAMADA, 2019. Gender differences in improvement of olderperson-specific quality of life after hearing-aid fitting. In: Disability and Health Journal. 12(2), pp. 209-213.

9. LABUDOVÁ, J., D. NEMČEK \& M. BARDIOVSKÝ, 2014. Socialisation: dominant aspect of sport for people with physical disability. In: Sports, Physical Activity and Health 2014. Conference proceedings. Bratislava: Slovak Olympic Committee, pp. 154-161.

10. LADECKÁ, P., D. NEMČEK \& T. HARČARÍKOVÁ, 2019. Subjective well-being of students attending the special vocational school for children with physical disabilities: Gender differences. In: Ad Alta: Journal of Interdisciplinary Research. 9(2), pp. 427-431.

11. LOLAND, N.W., 1999. Some contradictions and tensions in elite sportsmen's attitudes towards their bodies. In: International Review for the Sociology of Sport. 34(3), pp. 291302.

12. LUNDQVIST, C., 2011. Well-being in competitive sport - The feel-good factor? A review of conceptual considerations of well-being. In: International Review of Sport and Exercise Psychology. 4(2), pp. 109-127.

13. McAlliSTER, D.R., A.R. MOTAMEDI, S.L. HAME, M.S. SHAPIRO \& F.J. DOREY, 2001. Quality of life assessment in elite collegiate athletes. In: American Journal of Medicine. 29(6), pp. 806-810.

14. MIKULIČ, M., P. GREGORA, L. BENKOVSKÝ \& P. PERÁČEK, 2015. The relative age effect on the selection in the Slovakia national football teams. In: Acta Facultatis Educationis Physicae Universitatis Comenianae. 55(2), pp. 122-131.

15. NEMČEK, D., 2014. Spokojnost' so sociálnymi vzt’ahmi a prostredím ako súčast' kvality života l'udí so sluchovým postihnutím z pohl'adu športovania vo vol’nom čase. In: Pohyb a zdravie Xl. Pohybová aktivita a zdravý životný štýl - šport a športový tréning. Trenčín: TU A. Dubčeka, pp. 110-116.

16. NEMČEK, D. 2016a. Cognitive element of subjective well-being of the Slovak population. In: Physical Activity, Health and Prevention. International Scientific Conference. Žilina: IPV Institute of Education, pp. 62-67.

17. NEMČEK, D. 2016b. Quality of life of people with disabilities from sport participation point of view. In: Acta Facultatis Educationis Physicae Universitatis Comenianae. 56(2), pp. 77-92.

18. NEMČEK, D. 2017. Self-esteem in people with physical disabilities: Differences between active and inactive individuals. In: Acta Facultatis Educationis Physicae Universitatis Comenianae. 57(1), p. 34-47. 
19. NEMČEK, D., P. KURKOVÁ \& J. WITTMANNOVÁ, 2019. Gender differences in subjective well-being of healthy high-school students. In: Acta Facultatis Educationis Physicae Universitatis Comenianae. 59(2), pp. 161-171.

20. NEMČEK, D., S. KRAČEK \& J. PERÁČKOVÁ, 2017. Rosenberg Self-Esteem Scale analyses among elite and competitive athletes, recreational athletes and inactive individuals. In: Journal of Physical Education and Sport. 17(5), pp. 2305-2310.

21. NEMČEK, D., J. LABUDOVÁ, J. PERÁČKOVÁ, H. MEDEKOVÁ, A. PAVLÍKOVÁ, S. KRAČEK, M. BARDIOVSKÝ \& S. HREBÍKOVÁ, 2011. Kvalita života seniorov a pohybová aktivita ako jej súčast' [Quality of Life in Seniors and Physical Activity as a Part of It]. Prešov, Slovakia: Michal Vaško

22. OMOROU, Y.A., M.L. ERPELDING, H. ESCALON \& A. VUILLEMIN, 2013. Contribution of taking part in sport to the association between physical activity and quality of life. In: Quality of Life Research. 22(8), pp. 2021-2029.

23. PAČESOVÁ, P., P. ŠMELA, \& S. KRAČEK, 2019. Personal well-being as part of the quality of life: Is there a difference in the personal well-being of women and men with higher level of anxiety trait regarding their sport activity? In: Physical Activity Review. 7, pp. 201-208.

24. PETT, M.A. 1997. Nonparametric statistics for health care research: Statistics for small samples and unusual distributions. Thousand Oaks, CA: Sage.

25. RICE, S.M., R. PURCELL, S. DE SILVA, D. MAWREN, P.D. McGORRY \& A.G. PARKER, 2016. The Mental Health of Elite Athletes: A Narrative Systematic Review. In: Sports Medicine. 46(9), pp. 1333-1353.

26. RUIZ, J.R. J.L. MESA, I. MINGORANCE, A. RODRIGUES-CUARTERO \& M.J. CASTILLO, 2004. Sports requiring stressful physical exertion cause abnormalities in plasma lipid profile. In: Revista Espanola de Cardiologia. 57(6), pp. 499-506.

27. SIMON, J.E. \& C.L. DOCHERTY, 2014. Current health-related quality of life is lower in former Division I collegiate athletes than in non-collegiate athletes. In: American Journal of Sports Medicine. 42(2), pp. 423-429.

28. SMITH, A.L. 2003. Peer relationships in physical activity contexts: a road less travelled in youth sport and exercise psychology research. In: Psychology of Sport and Exercise. 4(1), pp. 25-39.

29. STAMBULOVA, N.B., 1994. Developmental sports career investigations in Russia: A post-perestroika analysis. In: The Sport Psychologist. 8, pp. 221-237. 
30. STEPHAN, Y. \& J. BILARD, 2003. Repercussions of Transition Out of Elite Sport on Subjective Well-Being: A One-Year Study. In: Journal of Applied Sport Psychology. 4(4), pp. 354-371.

31. TANABE, T., A.R. SNYDER, R.C. BAY, T.C. VALOVICH McLEOD, 2010. Representative Values of Health-Related Quality of Life Among Female and Male Adolescent Athletes and the Impact of Gender. In: Athletic Training and Sports Health Care. 2(3), pp. 106-112.

32. The WHOQOL Group. (1995). The World Health Organization Quality of Life Assessment (WHOQOL): Position paper from the World Health Organization. In: Social Science \& Medicine. 41(10), pp. 1403-1409.

33. WEISS, M.R. \& S.C. DUNCAN, 1992. The relationship between physical competence and peer acceptance in the context of children's sport participation. In: Journal of Sport \& Exercise Psychology. 14(2), pp. 177-191.

34. WERTHNER, P., \& T. ORLICK, 1986. Retirement experiences of successful Olympic athletes. In: International Journal of Sport Psychology. 17(5), pp. 337-363.

35. ZANNOTTI, M. \& D. PRINGUEY, 1992. A method for quality of life assessment in psychiatry: The S-QUA-L-A (Subjective QUAlity of Life Analysis). In: Quality of Life News Letter. 4(6). 